\title{
The Efficiency of Sampling Methods for Dendrometric Estimates of Thinned Stands of Pinus taeda L. in Santa Catarina, Brazil
}

\author{
Klerysson Julio Farias ${ }^{1}$, Thiago Floriani Stepka ${ }^{1}$, Marcos Felipe Nicoletti ${ }^{1}$, Luis Paulo Baldissera Schorr ${ }^{2}$, \\ Geedre Adriano Borsoi ${ }^{1}$, Nilton Sergio Novack Junior ${ }^{1}$, Eliana Turmina ${ }^{1}$, André Felipe Hess ${ }^{1}$, \\ Vinicius Chaussard Venturini ${ }^{1}$, Érica Barbosa Pereira de Souza ${ }^{1}$, Daniella Hoffmann ${ }^{1}$, \\ Vagner Alex Pesck ${ }^{3} \&$ Gerson dos Santos Lisboa ${ }^{4}$ \\ ${ }^{1}$ Department of Forest Engineering, Santa Catarina State University, Lages, Santa Catarina, Brazil \\ ${ }^{2}$ Department of Forest Sciences, Federal University of Lavras, Lavras, Minas Gerais, Brazil \\ ${ }^{3}$ Department of Forest Engineering, Central Western State University, Irati, Paraná, Brazil \\ ${ }^{4}$ Center for Training in Technosciences and Innovation, Federal University of Southern Bahia, Itabuna, Bahia, \\ Brazil \\ Correspondence: Thiago Floriani Stepka, Department of Forest Engineering, Santa Catarina State University, \\ Luiz de Camoes Avenue, 2090, Conta Dinheiro, Lages, Santa Catarina, Zipcode 88.520-000, Brazil. Tel: \\ 55-49-3289-9256. E-mail: thiago.stepka@udesc.br
}

Received: June 16, 2019

doi:10.5539/jas.v11n17p218
Accepted: August 3, $2019 \quad$ Online Published: October 15, 2019

URL: https://doi.org/10.5539/jas.v11n17p218

\begin{abstract}
This study aimed to compare the efficiency of the sampling methods: Fixed Area, Bitterlich, Prodan and Modified Prodan to estimate the commercial volume and other dendrometric estimators for a 34 years old of Pinus taeda L. stands located in Campo Belo do Sul, Santa Catarina, Brazil. It were distributed a total of 10 sample units of the following methods: Fixed Area with 200, 400 and $500 \mathrm{~m}^{2}$ of area, Bitterlich, Prodan and Modified Prodan were distributed, both with 6, 7, 8, 9 and 10 trees. In addition to collecting dendrometric data, the installation time of the sample units was timed, whereby the relative efficiency for each method was calculated. The comparison between the harvest volumes and the volumes estimated by the methods was performed by the Skott Knott test, and the results that did not differ statistically were weighted by the parameters of relative error, relative efficiency and proximity to harvest. All variations of the Modified Prodan and Prodan methods had sample insufficiency. The number of trees per hectare presented higher values for the $200 \mathrm{~m}^{2}$ Fixed Area method and lower values for Prodan with 10 trees. Prodan with 6 trees got the shortest time. The Bitterlich method obtained sample adequancy at $10 \%$ error and presented the best result. Among the alternative methods to Fixed Area, Modified Prodan with 7 trees can be indicated for pilot inventory. However, when more precise results are needed, the Bitterlich method is indicated.
\end{abstract}

Keywords: forest inventory, variable area sample units, relative efficiency, sampling systems

\section{Introduction}

Currently, the Brazilian silviculture corresponds to an area of 7.8 million hectares and $20.5 \%$ belongs to the genus Pinus, which presents greater quantity in the southern region of the country. In this region, the forest market is structured, with a production divided between the pulp, paneling, sawing and biomass sectors, moving much of the economy (IBÁ, 2017).

The planning and the management of the forest resources are fundamental to guarantee the production sustainability. According to Sanquetta et al. (2009), the stands efficient evaluation through the forest inventory is decisive for choosing the most suitable methodologies from the technical (e.g., thinning season) to the economic point (e.g., forest revenue estimate).

In the literature, several sampling methods are listed, but it is important to highlight that the variables measuring method by the installation of fixed area plots is the oldest and the most used by companies. This method consists of the selection of the individuals proportionally to the study area or sample unit and weighted to the unit area (hectare) (Sanquetta et al., 2009). 
In the Bitterlich method, the selection of trees is performed with probability to the basal area, or at the table of diameter and at the frequency, that is, the inclusion of an individual is proportional to its size and its frequency at the point. The sample unit is established through a $360^{\circ}$ rotation from a reference point, with the $\mathrm{DBH}$ (diameter at 1.3 meters from the ground) of each tree with the angle $\beta$ deciding, according to the principle, which individuals will be included (Péllico Netto \& Brena, 1997).

For the Prodan method, the procedure consists of choosing a point and turning counterclockwise and measuring the six nearest trees, where the sixth tree is considered the reference tree, because in addition to obtaining the DBH it will be measured the distance from the chosen point, up to half of the base of its trunk, which will be used in the future to generate the population data (Péllico Netto \& Brena, 1997).

The number of trees is constant in this method because, according to Prodan (1968), the variation coefficient of the sixth tree becomes constant, decreasing the efforts to measure its sample units (Pellico Netto \& Brena, 1997). However, it should be noted that this constancy may be different depending on the evaluated population type. Therefore, changes in the number of trees of this method are found in the literature, such as the study by Paidon and Finger (2010), where the authors performed the data collection in Pinus taeda L. stands by the modification in the Prodan method, with sample units with 12 trees.

It is important to emphasize that the determination of the method to be used may vary according to the forest management system, and when the forest alignment is known, variations in shape and area of the sample units of the fixed area method are usually used. In contrast, in situations where the distribution of individuals is irregular, circular sampling units of this method or even other methodologies with variable areas are used.

According to Freese (1962), the efficiency of the sampling methods must include the cost as an indicator to compare sample unit sizes, and the method must obtain the least cost for the desired precision. Péllico Netto \& Brena (1997) point out that when comparing different sampling methods, the methods must be transformed to the same basis of comparison, by calculating the inverse of the products of the squares of the variation coefficient by the cost.

Several researches have been performed with the purpose of optimizing the area of the sample units, as well as the use of alternative methods, aiming the best cost-benefit relation of data collection, such as Bitterlich, Prodan and Strand, being possible to highlight the works of Costa et al. (2010), Péllico Netto et al. (2012), Druszcz et al. (2013), Retslaff et al. (2014), Teo et al. (2014), and Miranda et al. (2015).

In this context, this study aimed to compare the efficiency of the Fixed Area, Bitterlich, Prodan and Modified Prodan sampling methods in stands of Pinus taeda L. to estimate the commercial volume and other dendrometric estimators in the region of Campo Belo do Sul, Santa Catarina, Brazil. The hypothesis of this research was to verify the performance of the variable area sampling methods compared to the fixed area method in order to get the time spent and the accuracy of the forest inventory.

\section{Method}

\subsection{Location of the Study Area}

The study area is located in the municipality of Campo Belo do Sul, in the plateau region of Santa Catarina, state of Santa Catarina, Brazil (Figure 1). According to the Köppen classification, the climate is classified as Cfb, with $1647 \mathrm{~mm}$ rainfall and $16^{\circ} \mathrm{C}$ average annual temperature (Alvares et al., 2013).

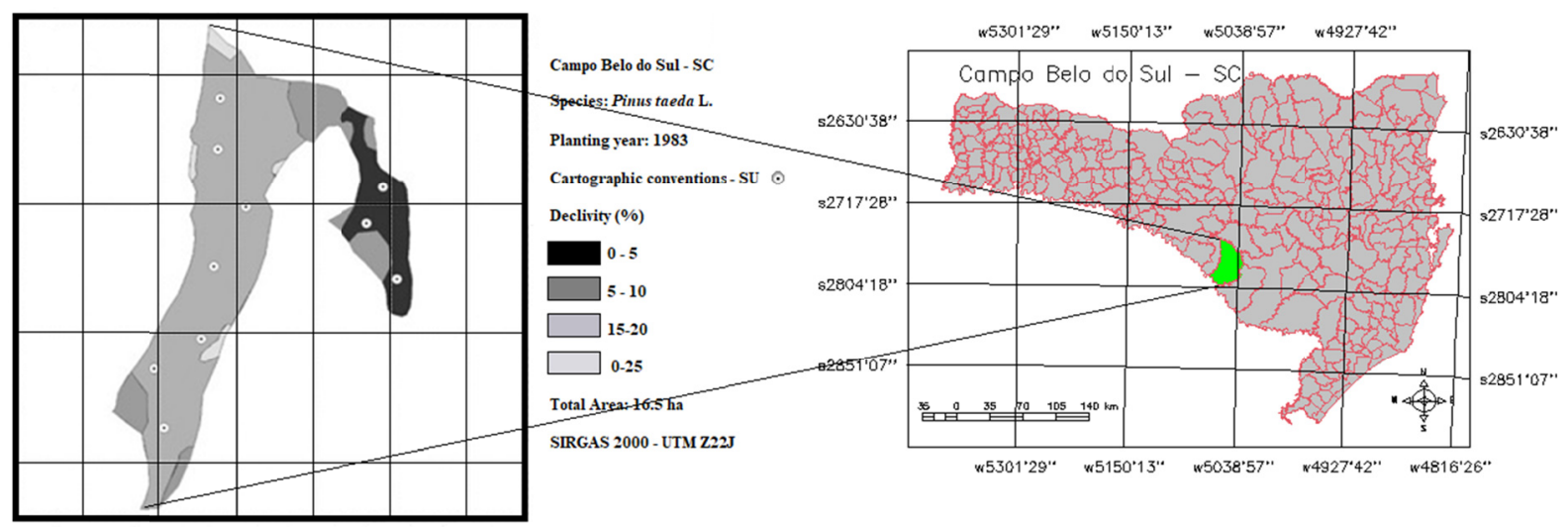

Figure 1. Location of study area and sample units distribution. 
The forest stand is constituted by Pinus taeda L. trees of 34 years of age. The stand was submitted to 5 thinnings $(8,12,18,22,28$ years old, with a mean cutting intensity of $30 \%)$ and 5 prunings $(3,4,5,6,7$ years, up to $5.8 \mathrm{~m}$ in height), as well as it was very affected by the natural regeneration. Currently, the stand density is 252 individuals per hectare.

\subsection{Sampling Procedures and Data Collecting}

Within the 16.5 hectares, 10 sample units were randomly assigned to the following methods: Fixed Area (with circular units), Bitterlich and Prodan, being that the first method had variations in the area of the sample unit and the last, variation regarding to the number of trees selected and the unit center positioning.

In the Fixed Area method, circular sample units with 200 (AF200), 400 (AF400) and 500 (AF500) $\mathrm{m}^{2}$ of area were installed. We measured the DBH (diameter at 1.30 meters in height) and the height of all trees using the caliper and the Vertex IV ${ }^{\circledR}$ ultrasound hypsometer, respectively.

At the same point, corresponding to the center of the fixed area sample units, others sample units were installed by the Bitterlich method (BTL), where all DBH and all heights were measured using a basal area factor of 1.5.

For the Prodan method, the 10 sample points (located in the same locations of the previous methods) were analyzed with five variations in the number of trees: 6 (P6), 7 (P7), 8 (P8), 9 (P9) and 10 (P10) trees. The DBH and the height of trees closer to the unit central point were measured, and the distance of the sixth, seventh, eighth, ninth and tenth trees respectively for each variation of the method were used to calculate the estimators.

In the case of the Prodan method, a modification proposed by Pellico Netto et al. (2012) for the determination of the sample unit center, which in this case was an arboreal individual located near the sampling units center of the previous methods. Samples were also analyzed with 6 (PM6), 7 (PM7), 8 (PM8), 9 (PM9) and 10 (PM10) trees, also measuring their radius.

In all methods, the time spent per sampling unit (from the installation to the measurement of trees) was measured with the aid of the chronometer.

\subsection{Statistics and Data Analysis}

The commercial volume estimation was performed through the fifth degree polynomial tapering function, which was developed from the cube of 72 trees of the place, which was arranged as follow:

$$
\begin{gathered}
\mathrm{b}_{0}=1.1562 ; b_{1}=-3.6219 ; \mathrm{b}_{2}=16.7870 ; \mathrm{b}_{3}=-36.8997 ; \mathrm{b}_{4}=35.3247 ; \mathrm{b}_{5}=-12.7804 \\
\mathrm{v}=\mathrm{K}^{*} \mathrm{~d}^{2 *}\left[\begin{array}{c}
\mathrm{c}_{0}^{2} \mathrm{hi}+\mathrm{c}_{0} \mathrm{c}_{1} \mathrm{hi}^{2}+\left(\frac{2}{3} \mathrm{c}_{0} \mathrm{c}_{2}+\frac{1}{3} \mathrm{c}_{1}^{2}\right) \mathrm{hi}^{3}+\left(\frac{1}{2} \mathrm{c}_{0} \mathrm{c}_{3}+\frac{1}{2} \mathrm{c}_{1} \mathrm{c}_{2}\right) \mathrm{hi}^{4}+ \\
\left(\frac{2}{5} \mathrm{c}_{0} \mathrm{c}_{4}+\frac{2}{5} \mathrm{c}_{1} \mathrm{c}_{3}+\frac{1}{5} \mathrm{c}_{2}^{2}\right) \mathrm{hi}^{5}+\left(\frac{1}{3} \mathrm{c}_{0} \mathrm{c}_{5}+\frac{1}{3} \mathrm{c}_{1} \mathrm{c}_{4}+\frac{1}{3} \mathrm{c}_{2} \mathrm{c}_{3}\right) \mathrm{hi}^{6}+\left(\frac{2}{7} \mathrm{c}_{1} \mathrm{c}_{5}+\frac{2}{7} \mathrm{c}_{2} \mathrm{c}_{4}+\frac{1}{7} \mathrm{c}_{3}^{2}\right) \mathrm{hi}^{7}+ \\
\left(\frac{1}{4} \mathrm{c}_{3} \mathrm{c}_{5}+\frac{1}{4} \mathrm{c}_{3} \mathrm{c}_{4}\right) \mathrm{hi}^{8}+\left(\frac{2}{9} \mathrm{c}_{3} \mathrm{c}_{5}+\frac{1}{9} \mathrm{c}_{4}^{2}\right) \mathrm{hi}^{9}+\frac{1}{5} \mathrm{c}_{4} \mathrm{c}_{5} \mathrm{hi}^{10}+\frac{1}{11} \mathrm{c}_{5}^{2} \mathrm{hi}^{11}
\end{array}\right]_{\mathrm{h} 1}^{\mathrm{h}}
\end{gathered}
$$

Where, $\mathrm{K}=\pi / 40.000 ; \mathrm{d}^{2}=$ squared diameter measured at $1.30 \mathrm{~m}$ above the ground $(\mathrm{cm})^{2} ; \mathrm{c}_{0}=\mathrm{b}_{0} ; \mathrm{c}_{1}=\mathrm{b}_{1} / \mathrm{h} ; \mathrm{c}_{2}=$ $\mathrm{b}_{2} / \mathrm{h}^{2} ; \ldots \mathrm{c}_{\mathrm{n}}=\mathrm{b}_{\mathrm{n}} / \mathrm{h}^{2} ; \mathrm{hi}=$ height at i position $(\mathrm{m}) ; \mathrm{h}=$ total height $(\mathrm{m})$.

Conversions of the basal area, number of individuals and commercial volume per hectare were performed in all methods, as said by Moscovich et al. (1999). The Relative Efficiency (REF) was calculated according to the criteria of Miranda et al. (2015), which uses the measurement average time of each of the methods and the variation coefficients obtained in the parameters estimation, by the expression:

$$
\mathrm{REF}=\frac{1}{\mathrm{~T} \times \mathrm{CV}^{2}}
$$

Where, REF: relative efficiency; T: time of measurement in minutes; CV: variation coefficient between sample units.

The value obtained by the harvest of the Pinus taeda trees represented the total volume obtained in the stand, that is, the parametric value. The volume per hectare result was obtained by dividing the sum of the weight of the timber assortments by the factor of $0.95 \mathrm{t} / \mathrm{m}^{3}$, which was the comparison basis of the results obtained in the sampling methods.

The Bartlett test was used to verify the variances homogeneity of the volume data obtained in the Fixed Area, Bitterlich, Prodan and Modified Prodan methods (Druszcz et al., 2010). In view of this result (variances homogeneity occurrence), the mean of the estimates generated by the methods and the harvest value were compared by the Scott Knott test at $95 \%$ of probability (Ribeiro et al., 2010). 
For the selection of the best method, the values of relative efficiency, relative error, and proximity to the volume obtained at harvest were weighted. For that, a score was determined for each of the variables, and the method that obtained the highest score was the one selected. Only those methods that did not obtain statistical difference by the Skott-Knott test (95\% probability) were submitted to this analysis.

\section{Results}

The harvest of trees generated a total of $8,144.86 \mathrm{t}$ of logs, and, applying the conversion factor, the result was $8,541.96 \mathrm{~m}^{3}$ in 16.5 hectares, which corresponds to $517.6 \mathrm{~m}^{3} / \mathrm{ha}$. The descriptive statistics of the estimated volume per hectare, the inventory error, and the sample unit areas are shown in Table 1, as demonstrated by the Scott-Knott test for analysis of values closer to that obtained at harvest.

Table 1. Descriptive statistics for volume per hectare $\left(\mathrm{m}^{3} \mathrm{ha}^{-1}\right)$ for the study area

\begin{tabular}{lllllllllll}
\hline Method & PA & CVSA & CV & ADQ & $\overline{\mathbf{x}}$ & $\mathbf{S x}^{\mathbf{2}}$ & $\mathbf{S} \overline{\mathbf{x}}$ & $\mathbf{S}^{\mathbf{2}}$ & $\mathbf{A E}$ & $\mathbf{R E}$ \\
\hline AF200 & 200 & - & 30.53 & 38 & $811.8 \mathrm{c}$ & 6143.7 & 78.4 & 61436.9 & 177.3 & 21.8 \\
AF400 & 400 & - & 18.18 & 15 & $713 \mathrm{c}$ & 1639.6 & 40.5 & 16803.1 & 91.6 & 12.8 \\
AF500 & 500 & - & 24.27 & 24 & $691.6 \mathrm{c}$ & 2732.8 & 52.3 & 28181.6 & 118.3 & 17.1 \\
BTL & - & - & 12.96 & 9 & $528.7 \mathrm{~b}$ & 469.8 & 21.7 & 4698.0 & 49.0 & 9.3 \\
P6 & $216.5^{*}$ & 34.28 & 38.55 & 60 & $747.9 \mathrm{c}$ & 8313 & 91.2 & 83129.8 & 206.3 & 27.6 \\
P7 & $274.9^{*}$ & 20.24 & 30.58 & 38 & $674 \mathrm{c}$ & 4247.6 & 65.2 & 42475.8 & 147.4 & 21.9 \\
P8 & $332.0^{*}$ & 28.92 & 26.12 & 29 & $653.8 \mathrm{c}$ & 2916.4 & 54 & 29164.1 & 122.2 & 18.7 \\
P9 & $435.4^{*}$ & 26.39 & 26.13 & 29 & $579.7 \mathrm{~b}$ & 2295 & 47.9 & 22949.9 & 108.4 & 18.7 \\
P10 & $520.1^{*}$ & 22.65 & 27.56 & 32 & $512.9 \mathrm{~b}$ & 1997.6 & 44.7 & 19976 & 101.1 & 19.7 \\
PM6 & $203.1^{*}$ & 26.90 & 36.87 & 55 & $804.7 \mathrm{c}$ & 8804.6 & 93.8 & 88046.1 & 212.3 & 26.4 \\
PM7 & $347.1^{*}$ & 27.06 & 33.46 & 45 & $546.5 \mathrm{~b}$ & 3344.8 & 57.8 & 33448.1 & 130.8 & 23.9 \\
PM8 & $446.7^{*}$ & 23.91 & 25.32 & 27 & $472.3 \mathrm{a}$ & 1429.5 & 37.8 & 14295 & 85.5 & 18.1 \\
PM9 & $569.6^{*}$ & 27.85 & 28.81 & 34 & $424.4 \mathrm{a}$ & 1494.4 & 38.7 & 14943.7 & 87.4 & 20.6 \\
PM10 & $667.8^{*}$ & 18.17 & 28.74 & 34 & $402.3 \mathrm{a}$ & 1337.1 & 36.6 & 13371.1 & 82.7 & 20.6 \\
CR & - & - & - & - & $517.6 \mathrm{~b}$ & - & - & - & - & - \\
\hline
\end{tabular}

Note. Different letters represent a significant difference at a level of 0.05 probability according to Scott-Kott's test at the 5\% probability level of error in the mean volumetric. AF200: Fixed Area $200 \mathrm{~m}^{2}$; AF400: Fixed Area $400 \mathrm{~m}^{2}$; AF500: Fixed area $500 \mathrm{~m}^{2}$; BTL: Bitterlich; P6: Prodan with 6 trees; P7: Prodan with 7 trees; P8: Prodan with 8 trees; P9: Prodan with 9 trees; P10: Prodan with 10 trees; PM6: Modified Prodan with 6 trees; PM7: Modified Prodan with 7 trees; PM8: Modified Prodan with 8 trees; PM9: Modified Prodan with 9 trees; PM10: Modified Prodan with 10 trees; CR: Harvest; PA: plot area in $\mathrm{m}^{2}$; CVAP: Variation coefficient in\% for areas of Prodan and Modified Prodan sample units; CV: Variation coefficient in\%; ADQ: number of units needed to achieve a $10 \%$ error; $\overline{\mathrm{x}}$ : Arithmetic mean $\left(\mathrm{m}^{3}\right) ; \mathrm{S}^{2}$ : variance of the mean; $\mathrm{S}$ : standard deviation of the mean; $\mathrm{S}^{2}$ : variance $\left(\mathrm{m}^{3} \mathrm{ha}^{-1}\right)^{2}$; AE: absolute sampling error $\left(\mathrm{m}^{3} \mathrm{ha}^{-1}\right)$; RE: Relative sampling error.

The estimation of the volume per hectare showed a great variation among the methods, with the lowest average being $402.3 \mathrm{~m}^{3} \mathrm{ha}^{-1}$ of the PM10 method and the highest was $811.8 \mathrm{~m}^{3} \mathrm{ha}^{-1}$ of the AF200. This study showed a tendency to generate smaller estimates as the number of trees in the Modified Prodan method increased.

It was observed that although the AF200 and PM6 methods presented the average size of their similar sample units, there was a difference in the sample adequacy, with 38 and 55 units being required, respectively.

This fact is mainly due to the irregular distribution of the individuals in the stand, which directly interferes in the Prodan methods estimations, as demonstrated by the variation coefficient of their sample units, making it require a greater number of sample units to obtain the sample adequacy.

Figure 2 shows that the methods which presented the highest relative efficiency were those which presented the best relation between the coefficient of variation and the time spent per sample unit. The time average showed only the methods that presented the greatest difficulties for the installation of its sample units. 


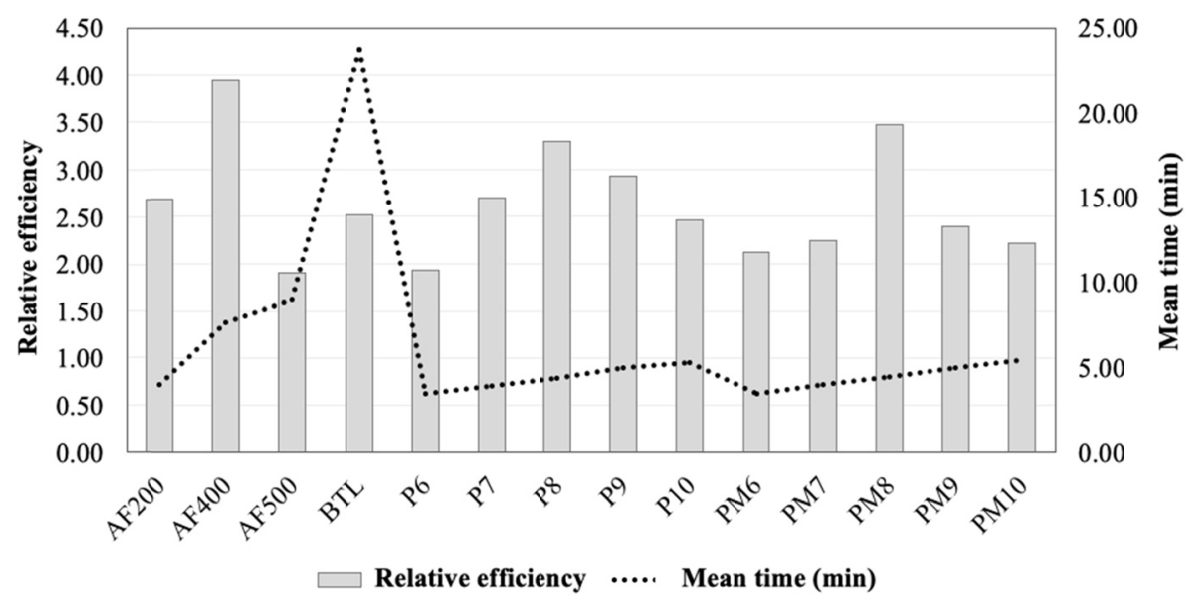

Figure 2. Relative efficiency and average time spent to perform the sample unit, considering the estimated volume per hectare in each method.

Regarding the time average for installation of the sample units, the best results were obtained by the variations in Prodan and Modified Prodan methods, with the shortest time being to P6. These methods were characterized by a shorter time due to the low number of trees and the little interference of natural regeneration.

However, the Bitterlich method proved to be the most time-consuming, since it was directly affected by natural regeneration, and also due to the difficulty of identifying the most distant trees, requiring greater attention in the choice of individuals that would be part of the Angle-count Sampling (ACS).

The mean basal area estimate per hectare (Table 2) ranged from 25.6 (PM10) to 50.9 (PM6) m² ha ${ }^{-1}$, while the estimated number of individuals per hectare was 145 (PM10) and 286 (PM6). The variation coefficient for the number of trees per hectare was $14.69 \%$, while for the basal area it was $15.46 \%$.

It was observed that both estimates obtained the same behavior, and the Prodan and Modified Prodan methods showed a tendency to decrease the number of trees and the estimated basal area as the number of trees in the sample unit increases.

The Bitterlich method presented the lowest variation coefficient for tree numbers and basal area per hectare. This shows that the number of trees per sample unit was similar, thus solving the problems of heterogeneous distribution of trees at the study site.

The PM10 method had the lowest mean, not differing from PM9 and PM8. PM7 together with P10, P9, BTL and CR are statistically the same according to the Scott-Kott's test. AF200, AF400, AF500, P6, P7, P8 and PM6 presented the highest averages.

The PM7 and PM10 methods presented the same scores, however, the first one was closer to the commercial volume that was actually obtained in the area. P9 presented the second smallest relative error but took disadvantage in relative efficiency. Bitterlich was considered the best method, despite having the second worst performance in relative efficiency, its error was smaller and the result of its estimates was closer to the harvest. 
Table 2. Information of density and basal area per hectare obtained in each method

\begin{tabular}{lllll}
\hline Method & N $\left(\mathbf{I n d} \mathbf{h a}^{-\mathbf{1}}\right)$ & $\mathbf{C V N}(\mathbf{\%})$ & $\mathbf{G}\left(\mathbf{m}^{\mathbf{2}} \mathbf{h a} \mathbf{~}^{-\mathbf{1}}\right)$ & $\mathbf{C V G} \mathbf{( \% )}$ \\
\hline AF200 & 285 & 16.6 & 49.8 & 28.2 \\
AF400 & 258 & 8.0 & 44.3 & 13.3 \\
AF500 & 252 & 11.3 & 43.1 & 20.9 \\
BTL & 212 & 10.8 & 35.1 & 12.8 \\
P6 & 272 & 32.4 & 47.2 & 35.7 \\
P7 & 243 & 19.6 & 46.1 & 29.4 \\
P8 & 236 & 25.8 & 43.8 & 29.3 \\
P9 & 21.2 & 37.1 & 25.7 \\
P10 & 182 & 20.5 & 34.7 & 24.4 \\
PM6 & 286 & 30.4 & 56.0 & 35 \\
PM7 & 30.9 & 37.2 & 28.6 \\
PM8 & 198 & 23.5 & 31.8 & 22.3 \\
PM9 & 174 & 26.0 & 28.9 & 25.6 \\
PM10 & 157 & 17.5 & 27.9 & 25.4
\end{tabular}

Note. AF200: Fixed Area $200 \mathrm{~m}^{2}$; AF400: Fixed Area $400 \mathrm{~m}^{2}$; AF500: Fixed area $500 \mathrm{~m}^{2}$; BTL: Bitterlich; P6: Prodan with 6 trees; P7: Prodan with 7 trees; P8: Prodan with 8 trees; P9: Prodan with 9 trees; P10: Prodan with 10 trees; PM6: Modified Prodan with 6 trees; PM7: Modified Prodan with 7 trees; PM8: Modified Prodan with 8 trees; PM9: Modified Prodan with 9 trees; PM10: Modified Prodan with 10 trees; N: Number of trees per hectare $\left(\right.$ Ind ha $\left.{ }^{-1}\right)$; CVN (\%): Variation coefficient for number of trees of each method; G: Basal Area per hectare $\left(\mathrm{m}^{2}\right.$ $\left.\mathrm{ha}^{-1}\right)$; CVG (\%):Variation coefficient for the basal area of each method.

Table 3 shows the score and weighting of the results of the methods that did not differ significantly from the commercial volume obtained by harvest.

Table 3. Weighting of the results of the best sampling methods

\begin{tabular}{lllll}
\hline Method & Proximity & Relative error & Relative Efficiency & Total score \\
\hline BTL & 4 & 4 & 2 & 10 \\
P9 & 2 & 3 & 1 & 6 \\
PM7 & 3 & 1 & 3 & 7 \\
PM10 & 1 & 2 & 4 & 7
\end{tabular}

Note. BTL: Bitterlich; P9: Prodan with 9 trees; PM7: Modified Prodan with 7 trees; PM10: Modified Prodan with 10 trees.

\section{Discussion}

The average number of trees per hectare presented great variation for the methods, with higher values for the Fixed Area method with sample units of $200 \mathrm{~m}^{2}$. This result confronts those obtained by Nascimento et al. (2015), who found overestimations when analyzing the methods of Bitterlich, Prodan and Strand to the census of a fragment of Mixed Ombrophylous Forest located in the state of Parana. In addition, Druczsz et al. (2010) also observed this tendency of overestimation by the Prodan and Bitterlich methods.

According to Miranda et al. (2015), the number of trees per hectare is not influenced directly by the method, but rather by the sample unit size, which will be determinant in the generation of more accurate estimates. However, the method with the largest sample area (Prodan with 10 trees) was the one that obtained the least estimate of the number of trees, which agrees with was presented by the author, demonstrating that the method can interfere in the estimation.

Druszcz et al. (2010) demonstrated a similar situation, once the authors concluded that the Fixed Area method was more accurate and efficient for estimating the mean DBH and the number of trees per hectare, while the Bitterlich method obtained better results for estimating the basal area and the volume per hectare. 
In the study conducted by Druszcz et al. (2012), which compared forest inventories by Bitterlich and in-line conglomerate in a Pinus taeda stand, the Bitterlich was the method with the best result, and it was about $45 \%$ more efficiency for basal area and volume estimates.

A similar result was obtained in this study because although it did not obtain the best relative efficiency, the Bitterlich method showed less error and greater fidelity to the volume obtained by harvest. Santos et al. (2016), comparing the Fixed-Area and Bitterlich methods in Eucalyptus grandis stands emphasizes that both methods did not differ statistically from each other in basal area as well as in volume, thus presenting the equivalence of precision methods.

Ubialli et al. (2009) in his comparative study of sampling methods and methods to estimate the basal area for groups of species in an ecotonal forest in the north of Mato Grosso observed that the sample units with smaller area obtained a greater real error, compared to the value obtained in the census. Nonetheless, the units with the largest area obtained a larger sampling error. Therefore, according to the author, both the real error and the sample error are strongly influenced by the sample intensity. This assertion is confirmed in this study, since there is no tendency to decrease the error with the increase of the sample unit.

The Bitterlich method was the one that obtained the least sampling error relative to the volume in this study, requiring only nine sample units to achieve sufficiency by fixing a 10\% error. Miranda et al. (2015) demonstrated that for the volume variable the Bitterlich method provided more accurate results. In the estimation of average volume per hectare, the lowest sampling error was for the Bitterlich method $( \pm 4.30 \%)$. This situation was observed when the Bitterlich method was compared with the volume obtained at harvest, and it was the one that came closest.

As for the time average, it was observed that the Prodan method obtained less time demand for the data collection. Gomes et al. (2011) analyzed the performance of Prodan and Bitterlich methods in a non-thinned Eucalyptus sp. stands of 8 years and also obtained less time spent per sampling unit with the Prodan method. According to the authors, the time savings between one and the other was 14 minutes, being the method of the six trees more economically feasible. However, there are external factors that can influence the time spent to collect the data in inventories, such as meteorological and access conditions, site topography and vegetation density (Vibrans et al., 2010).

Notwithstanding, by analyzing the relative efficiency, the Fixed Area method with sample units of $400 \mathrm{~m}^{2}$ obtained the best result. Téo et al. (2014) obtained different results, and the Fixed Area method did not present the best performance, which was overcome by the Strand method, being ahead of Bitterlich and Prodan. When compared by analysis of variances, all methods were statistically the same, according to the authors.

Differently, for Miranda et al. (2015), the Bitterlich was the most efficient method for estimating the variable number of trees per hectare, basal area and volume per hectare. On the other hand, the authors emphasize that the results may be conflicting with those found in the literature due to differences related to the study species, spacing, silvicultural treatments and, mainly, forest heterogeneity. In this way, we should verify the need for methods that are more efficient for each situation.

\section{Conclusion}

In conclusion, the statistical analyses allowed identify that:

$>$ The variations of the Prodan and Prodan modified methods were interfered by the sample intensity, and more repetitions should be performed to obtain better estimators.

$>\quad$ The number of trees, the basal area and the volume per hectare presented higher values for the Fixed Area methods with sample units of $200 \mathrm{~m}^{2}$ and lower values for the Prodan method with 10 trees.

$>\quad$ The shortest time for installation and measurement of the individuals per sample unit was obtained with the Prodan method with 6 trees, while the highest relative efficiency was obtained by the Fixed Area method with sample units of $400 \mathrm{~m}^{2}$.

Bitterlich's method was characterized by having a sampling error of $10 \%$ and also obtained better results in the weighting but it showed the largest time spent to install its sample unit due to the great difficulty due to natural regeneration in the area.

$>$ Among the alternative methods to Fixed Area, Modified Prodan with 7 trees stood out for having an estimate of volume that did not differ statistically from the harvest result and a shorter time, which can be indicated for situations that need faster results, as a pilot inventory. However, when more precise results are needed, the Bitterlich method is indicated, although it requires a longer time for data collection. 


\section{Acknowledgements}

The authors are grateful for the support of the Santa Catarina State University, Department of Forest Engineering and its Graduate Program. The FAPESC (Foundation for Research Support of the Santa Catarina State)-case number 2017TR639-financial assistance for research groups.

\section{References}

Alvares, C. A., Stape, J. L., Sentelhas, P. C., de Moraes, G., Lonardo, J., \& Sparoveck, G. (2013). Köppen’s climate classification map for Brazil. Meteorologische Zeitschrift, 22(6), 711-728. https://doi.org/10.1127/ 0941-2948/2013/0507

Costa, T. C. C., \& Regazzi, A. J. (2010). Amostragem para inventário florestal com probabilidade de superposição de parcelas circulares. Revista Árvore, 34(1), 137-145. https://doi.org/10.1590/S0100-6762 2010000100015.

Druszcz, J. P., Nakajima, N. Y., Pellico Netto, S., \& Yoshitani Júnior, M. (2010). Comparação entre os métodos de amostragem de Bitterlich e de Área Fixa com parcela circular em plantação de Pinus taeda. Floresta, 40(4), 232-248. https://doi.org/10.5380/rf.v40i4.20326

Druszcz, J. P., Nakajima, N. Y., Péllico Netto, S., Machado, S. A., Mello, A. A., \& Campos, A. P. G. (2012). Eficiência de inventário florestal com amostragem ponto de Bitterlich e conglomerado em linha em plantação de Pinus taeda. Floresta, 42(3), 527-538. https://doi.org/10.5380/rf.v42i3.25453

Druszcz, J. P., Nakajima, N. Y., Péllico Netto, S., Machado, S. A., Rosot, N. C., \& Bamberg, R. (2013). Eficiência de duas variações estruturais do método de amostragem de área fixa em plantações de Pinus taeda. Floresta, 43(4), 621-632. https://doi.org/10.5380/rf.v43i4.29928

Freese, F. (1962). Elementary forest sampling. Washington: Forest Service, Agriculture Handbook.

Gomes, K. B. P., Machado Filho, V. A., Silva, V. P., \& Silva, A. G. (2011). Comparação dos Métodos de Amostragem Casual Simples: Bitterlich e Prodan. Revista Agrogeoambiental, 3(1), 101-104. https://doi.org/ 10.18406/2316-1817v3n12011306

IBÁ (Indústria Brasileira de Árvores). (2017). Anuário Estatístico 2017. Retrieved January 2, 2018, from http://www.iba.org

Miranda, D. L. C., Francio, J., Santos, J. P., Sanquetta, C. R., \& Dalla Corte, A. P. (2015). Precisão e eficiência relativa de métodos de amostragem em teca. Pesquisa Florestal Brasileira, 35(83), 247-256. https://doi.org/10.4336/2015.pfb.35.83.638

Moscovich, F. A., Brena, D. A., \& Longhi, S. J. (1999). Comparação de diferentes métodos de amostragem, de área fixa e variável, em uma floresta de Araucaria angustifolia. Ciência Florestal, 9(1), 173-191. https://doi.org/10.5902/19805098375

Nascimento, R. G. M., Da Silva, L. C. R., Barbeiro, L. S. S., Wojciechowski, J. C., Péllico Netto, S., \& Machado, S. A. (2015). Efeito da árvore marginal nos estimadores populacionais obtidos por métodos de amostragem de área variável. Cerne, 21(1), 125-131. https://doi.org/10.1590/01047760201521011266

Padoin, V., \& Finger, C. (2010). Relações entre as dimensões da copa e a altura das árvores dominantes em povoamentos de Pinus taeda L. Ciência Florestal, 20(1), 95-105. https://doi.org/10.5902/198050981764

Péllico Netto, S., \& Brena, D. A. (1997). Inventário florestal. Curitiba: UFPR.

Péllico Netto, S., Orellana, E., Stepka, T. F., Lima, R., \& Figueiredo Filho, A. (2012). Comportamento probabilístico dos raios das sextas árvores no método de Prodan e estimativas dos parâmetros dendrométricos para Araucaria angustifolia (Bertol.) Kuntze nativa. Scientia Forestalis, 96(40), 517-524.

Retslaff, F. A. S; Lama, M. D., Doubrawa, B., Figueiredo Filho, A., \& Péllico Netto, S. (2014). Amostragem em Conglomerados pelo Método de Bitterlich em Floresta Ombrófila Mista. Nativa, 2(4), 94-98. https://doi.org/10.14583/2318-7670.v02n04a02

Ribeiro, A., Ferraz Filho, A. C., Mello, J. M., Ferreira; M. Z., Lisboa, P. M. M., \& Scolforo, J. R. S. (2010), Estratégias e metodologias de ajuste de modelos hipsométricos em plantios de Eucalyptus sp. Cerne, 16(1), 22-31. https://doi.org/10.1590/S0104-77602010000100003.

Sanquetta, C. R., Watzlawick, L. F., Dalla Côrte, A., Fernandes, L. A. V., \& Siqueira, J. D. P. (2009). Inventários florestais: planejamento e execução (2nd ed.). Curitiba: Multi-Grafhic. 
Santos, J. S., Mendonça, A. R., Silva, G. F., \& Fraga Filho, C. V. (2016). Método de amostragem de Bitterlich: Uma alternativade inventário forestal para pequenas propriedades rurais fomentadas. Agrária, 11(1), 46-https://doi.org/52. 10.5039/agraria.v11i1a5358

Téo, S. J., Schneider, C. R., Fiorentin, L. D., \& Costa, R. H. (2014). Comparação de métodos de amostragem em fragmentos de floresta ombrófila mista, em Lebon Régis, SC. Floresta, 44(3), 393-401. https://doi.org/ 10.5380/rf.v44i3.32687

Ubialli, J. A., Figueiredo Filho, A., Machado, S. A., \& Arce, J. E. (2009). Comparação de métodos e processos de amostragem para estimar a área basal para grupos de espécies em uma floresta ecotonal da região norte matogrossense. Acta Amazônica, 39(2), 305-314. https://doi.org/10.1590/S0044-59672009000200009.

Vibrans, A. C., Sevgnani, L., Lingner, D. V., Gasper, A. L., \& Sabbagh, S. (2010). Inventário florístico e florestal de Santa Catarina (IFFSC): Aspectos metodológicos e operacionais. Pesquisa Florestal Brasileira, 30 (64), 291-302. https://doi.org/10.4336/2010.pfb.64.291

\section{Copyrights}

Copyright for this article is retained by the author(s), with first publication rights granted to the journal.

This is an open-access article distributed under the terms and conditions of the Creative Commons Attribution license (http://creativecommons.org/licenses/by/4.0/). 